\title{
Plants as a source of Medicine among the Tribes residing in Kota block of Bilaspur district (C.G.) India Durgesh Dixena and D. K. Patel*
}

\author{
Department of Rural Technology and Social Development, \\ Guru Ghasidas Vishwavidyalaya (A Central University) \\ BILASPUR -495009 (C.G.) INDIA \\ *Corresponding Author \\ E-mail : dplantscience@yahoo.co.in
}

Received : 18.10.2019; Accepted : 04.11.2019

\begin{abstract}
Due to rich treatment potentials of varied Medicinal plants, these are efficiently utilized for curing a variety of disorders such as for digestive problem, respiratory problem, skin related disorders etc among the tribal peoples mostly living nearby the forest areas. The study area was tribal village adopted by GGV-Bilaspur (C.G.) under Unnat Bharat Abhiyan programme. Information gained related to the diverse Medicinal plants by personal interview among the tribal peoples. Tribals are efficiently using the plant resources available nearby them because of their easy availability, rich efficiency and no side effect etc.

\section{Introduction}

Plants are important and valuable bio-resources among the society. They are utilized for several purposes such as for food, fodder ,fuel and medicinal purposes etc. Forest includes rich plant diversity of different habits like herb, shrub and trees etc. It is also a major reservoir of different medicinal and aromatic plants utilized for treatment of varied disorders among the peoples/tribals.

Among the rich diversity of plants, these are also playing significant role in composition of biological diversity in certain ecological areas. These are major group of living beings in nature participating in multifold directions. Plant provides valuable products for all associating living species in natural habitat. Plants are providing shelter for varied bio species, supporting biogeo chemical cycle, natural management, environmental cleanup etc. Nature provides facilities to living beings for their long-term existence, continuous regeneration etc and are greatly responsible for their regular appearance in natural habitat. The process supports species diversity and further playing role in formation and development of biological diversity in specified ecological areas.

Biological diversity of specified ecological area includes association of all possible living species of different natural habitats. Rich species diversity are significantly playing role in successful growth and development of the biological diversity. Species composition in natural habitat is determined by the local environmental condition as well as by the active function of genes in living bio species. Rich biological diversity is characterized by the presence of several species variable in habit and habitats. Gradual appearance of vegetation showing diversity followed by their success in morphological and reproductive growth in natural habitat. Each one bio species willing to live in nature for long time and to extend the process for the same and to fulfil the targets plants are producing numerous seeds at the end of their life phase showing variance based on their species and are also regulated by the climatic condition. A success of morphological growth of the plant leads better development of the reproductive growth. Flowers are marked as a reproductive part of the plants including male and female reproductive parts in same or in different flowers.

Better pollination and further fertilization leads to the success of seeds development in plants, may be differing seasonally or annually depending on the plant species. A mature seed requires to transmit from one place to another by the potential participation of biotic or by abiotic agents in nature. By any one mode further seeds travel to different location in nature from their development site and are important aspects for dissemination of plant species in nature and also for maintaining existence of such plant in nature. In the 
TABLE -1: Plants as a source of NTFP (Non Timber Forest Product) among the Tribes.

\begin{tabular}{|c|c|c|c|c|c|c|c|c|}
\hline $\begin{array}{l}\text { S. } \\
\text { No }\end{array}$ & $\begin{array}{l}\text { Local } \\
\text { Name }\end{array}$ & $\begin{array}{l}\text { Botanical } \\
\text { Name }\end{array}$ & Family & Habit & $\begin{array}{l}\text { Parts } \\
\text { Used }\end{array}$ & $\begin{array}{c}\text { Season of } \\
\text { availability }\end{array}$ & $\begin{array}{l}\text { Traditional } \\
\text { Uses }\end{array}$ & $\begin{array}{l}\text { Propa- } \\
\text { gation }\end{array}$ \\
\hline 1. & Aam & $\begin{array}{l}\text { Mangifera } \\
\text { Indica }\end{array}$ & Anacardiaceae & Tree & Fruit & Summer & $\begin{array}{l}\text { Fruits are used } \\
\text { in vomiting and } \\
\text { stomach pain. }\end{array}$ & Seed \\
\hline 2. & AK & $\begin{array}{l}\text { Calotrophis } \\
\text { procera }\end{array}$ & Asclepiadaceae & Shrub & Leaf & $\begin{array}{l}\text { Whole } \\
\text { year }\end{array}$ & $\begin{array}{l}\text { Milky latex used } \\
\text { in inflammation, } \\
\text { skin related } \\
\text { disorders. }\end{array}$ & Seed \\
\hline 3. & Amla & $\begin{array}{l}\text { Emblica } \\
\text { officinalis }\end{array}$ & Euphorbiaceae & Tree & Fruit & Winter & $\begin{array}{l}\text { Fruit/Fruit juice } \\
\text { used for Digestive } \\
\text { purpose }\end{array}$ & Seed \\
\hline 4. & Babool & $\begin{array}{l}\text { Acacia } \\
\text { nilotica }\end{array}$ & Fabaceae & Tree & Stem & Whole year & $\begin{array}{l}\text { Twigs are used } \\
\text { as tooth brush, } \\
\text { dental problem }\end{array}$ & Seed \\
\hline 5. & $\begin{array}{l}\text { Bada } \\
\text { Bhringraj }\end{array}$ & $\begin{array}{l}\text { Tridax } \\
\text { procumbens }\end{array}$ & Asteraceae & Herb & Leaf & Winter & $\begin{array}{l}\text { Leaf juice used } \\
\text { as antiseptic } \\
\text { purpose }\end{array}$ & Seed \\
\hline 6. & Bel & $\begin{array}{l}\text { Aegle } \\
\text { marmelos }\end{array}$ & Rutaceae & Tree & Fruit & Summer & $\begin{array}{l}\text { Fruit pulp used } \\
\text { for Digestive } \\
\text { purpose }\end{array}$ & Seed \\
\hline 7. & Baheda & $\begin{array}{l}\text { Terminalia } \\
\text { bellerica }\end{array}$ & Combretaceae & Tree & Fruit & Winter & $\begin{array}{l}\text { Fruits used in } \\
\text { Digestive } \\
\text { Purpose }\end{array}$ & Seed \\
\hline 8. & Charota & Cassia Tora & Fabaceae & Herb & $\begin{array}{l}\text { Seed, } \\
\text { Leaf }\end{array}$ & Winter & $\begin{array}{l}\text { Used for Skin } \\
\text { Disease }\end{array}$ & Seed \\
\hline 9. & Chironji & $\begin{array}{l}\text { Buchanania } \\
\text { lanzan }\end{array}$ & Anacardiaceae & Tree & Seed & Summer & $\begin{array}{l}\text { Seeds are used } \\
\text { after grinding for } \\
\text { cooking }\end{array}$ & Seed \\
\hline 10. & $\begin{array}{l}\text { Dang } \\
\text { kanda }\end{array}$ & $\begin{array}{l}\text { Dioscorea } \\
\text { wallichii }\end{array}$ & Dioscoreaceae & $\begin{array}{c}\text { Herb/ } \\
\text { Climber }\end{array}$ & Tuber & Whole year & $\begin{array}{l}\text { Tuber } \\
\text { Useful for Tooth } \\
\text { pain, Digestive }\end{array}$ & \\
\hline 11. & Devna & $\begin{array}{l}\text { Ocimum } \\
\text { basilicum }\end{array}$ & Lamiaceae & Herb & Leaf & Whole year & $\begin{array}{l}\text { Useful in cough, } \\
\text { cold, skin } \\
\text { diseases }\end{array}$ & Seed \\
\hline
\end{tabular}




\begin{tabular}{|c|c|c|c|c|c|c|c|c|}
\hline $\begin{array}{l}\text { S. } \\
\text { No }\end{array}$ & $\begin{array}{l}\text { Local } \\
\text { Name }\end{array}$ & $\begin{array}{l}\text { Botanical } \\
\text { Name }\end{array}$ & Family & Habit & $\begin{array}{l}\text { Parts } \\
\text { Used }\end{array}$ & $\begin{array}{c}\text { Season of } \\
\text { availability }\end{array}$ & \begin{tabular}{|l} 
Traditional \\
Uses
\end{tabular} & $\begin{array}{l}\text { Propa- } \\
\text { gation }\end{array}$ \\
\hline 12. & Dhawai & $\begin{array}{l}\text { Woodfordia } \\
\text { fruiticosa }\end{array}$ & Lytharaceae & Shrub & Flower & Summer & $\begin{array}{l}\text { Decoction of } \\
\text { flowers are used } \\
\text { in dysentery, } \\
\text { stomach related } \\
\text { problem }\end{array}$ & $\begin{array}{l}\text { Stem } \\
\text { cutting }\end{array}$ \\
\hline 13. & Haldi & $\begin{array}{l}\text { Curcuma } \\
\text { longa }\end{array}$ & Zingiberaceae & Herb & Rhizome & Winter & $\begin{array}{l}\text { Utilized in } \\
\text { Inflammation, } \\
\text { skin diseases }\end{array}$ & Rhizome \\
\hline 14. & Harra & $\begin{array}{l}\text { Terminalia } \\
\text { chebula }\end{array}$ & Combretaceae & Tree & Fruit & Winter & $\begin{array}{l}\text { Fruits used in } \\
\text { Digestive Purpose }\end{array}$ & Seed \\
\hline 15. & Imli & $\begin{array}{l}\text { Tamarindus } \\
\text { indica }\end{array}$ & Fabaceae & Tree & Fruit & Summer & $\begin{array}{l}\text { Tamarind is } \\
\text { mainly for the } \\
\text { fruit and used } \\
\text { in Variety of } \\
\text { dishes }\end{array}$ & Seed \\
\hline 16. & Kaith & $\begin{array}{l}\text { Limonia } \\
\text { acidissima }\end{array}$ & Rutaceae & Tree & Fruit & Summer & $\begin{array}{l}\text { Fruits pulp used } \\
\text { for Stomach } \\
\text { related problems. }\end{array}$ & Seed \\
\hline 17. & Karanj & $\begin{array}{l}\text { Pongamia } \\
\text { pinnata }\end{array}$ & Fabaceae & Tree & Seed & Winter & $\begin{array}{l}\text { Fruits are used as } \\
\text { a herbal medicine }\end{array}$ & Seed \\
\hline 18. & Karhi & $\begin{array}{l}\text { Albizia } \\
\text { procera }\end{array}$ & Fabaceae & Tree & Bark & Whole year & $\begin{array}{l}\text { Decoction of bark } \\
\text { useful in cough } \\
\text { and cold }\end{array}$ & Seed \\
\hline 19. & Keu kand & $\begin{array}{l}\text { Costus } \\
\text { specious }\end{array}$ & Zingiberaceae & Herb & Rhizome & Winter & $\begin{array}{l}\text { Rhizome used } \\
\text { for stomach } \\
\text { related problems }\end{array}$ & Rhizome \\
\hline 20. & Kusum & $\begin{array}{l}\text { Schleichera } \\
\text { oleosa }\end{array}$ & Sapindaceae & Tree & Fruit & Monsoon & $\begin{array}{l}\text { Oil seed, } \\
\text { medicine and } \\
\text { soap }\end{array}$ & Seed \\
\hline 21. & Mahua & $\begin{array}{l}\text { Madhuca } \\
\text { indica }\end{array}$ & Sapotaceae & Tree & $\begin{array}{c}\text { Flower, } \\
\text { Fruit, } \\
\text { Root }\end{array}$ & Summer & As antidotes & Seed \\
\hline 22. & Neem & $\begin{array}{l}\text { Azadirachta } \\
\text { indica }\end{array}$ & Meliaceae & Tree & $\begin{array}{l}\text { Bark, } \\
\text { Leaf, } \\
\text { Seed }\end{array}$ & Summer & $\begin{array}{l}\text { Useful in Skin } \\
\text { problem, } \\
\text { Insecticidal } \\
\text { quality. }\end{array}$ & Seed \\
\hline
\end{tabular}




\begin{tabular}{|c|c|c|c|c|c|c|c|c|}
\hline $\begin{array}{l}\text { S. } \\
\text { No }\end{array}$ & $\begin{array}{l}\text { Local } \\
\text { Name }\end{array}$ & $\begin{array}{l}\text { Botanical } \\
\text { Name }\end{array}$ & Family & Habit & $\begin{array}{l}\text { Parts } \\
\text { Used }\end{array}$ & $\begin{array}{l}\text { Season of } \\
\text { availability }\end{array}$ & $\begin{array}{l}\text { Traditional } \\
\text { Uses }\end{array}$ & $\begin{array}{l}\text { Propa- } \\
\text { gation }\end{array}$ \\
\hline 23. & Nirgundi & Vitex negundo & Verbenaceae & Shrub & Stem & Whole year & $\begin{array}{l}\text { Twigs are used } \\
\text { as tooth brush, } \\
\text { dental problem }\end{array}$ & $\begin{array}{l}\text { Stem } \\
\text { cutting }\end{array}$ \\
\hline 24. & Palas & $\begin{array}{l}\text { Butea } \\
\text { monospema }\end{array}$ & Fabaceae & Tree & Bark & Whole year & $\begin{array}{l}\text { Used in Stomach } \\
\text { pain }\end{array}$ & Seed \\
\hline 25. & Sal & $\begin{array}{l}\text { Shorea } \\
\text { robusta }\end{array}$ & Dipterocarpaceae & Tree & $\begin{array}{l}\text { Bark, } \\
\text { Leaf }\end{array}$ & Whole year & $\begin{array}{l}\text { Resin-lohan - } \\
\text { Mosquito } \\
\text { repellent, Leaf } \\
\text { used for } \\
\text { preparation of } \\
\text { dona and pattal }\end{array}$ & Seed \\
\hline 26. & Tendu & $\begin{array}{l}\text { Diospyros } \\
\text { melanoxylon }\end{array}$ & Ebenaceae & Tree & Fruit & Summer & $\begin{array}{l}\text { Fruit pulp is } \\
\text { useful for } \\
\text { stomach }\end{array}$ & Seed \\
\hline 27. & Tulsi & Ocinum sanct & Im Lamiaceae & Herb & Leaf & Whole year & $\begin{array}{l}\text { Useful in cough, } \\
\text { cold, skin } \\
\text { diseases }\end{array}$ & Seed \\
\hline 28. & Vasaka & $\begin{array}{l}\text { Adhotoda } \\
\text { vasica }\end{array}$ & Acanthaceae & Shrub & Leaf & Whole year & $\begin{array}{l}\text { Leaf used in } \\
\text { Respiratory } \\
\text { problem }\end{array}$ & $\begin{array}{l}\text { Stem } \\
\text { cutting }\end{array}$ \\
\hline
\end{tabular}

presence of better environmental condition seeds further convert into new plants like to their parental ones and is important step towards their regeneration. All the plants living in nature are not similarly equal in term of their seed development during the tenure of plant life. Such plants are well gifted by nature regarding their continuous appearance in their natural habitat using the vegetative plant parts like root, stem, leaf etc.

The plant modification parts like bulb, tuber, rhizome, corm etc are equally potent in term of capability to develop into new plants like their mother plants in the support of better environmental condition. Plants are either developing new plants by seeds or by the potential application of vegetative modes but some plants in nature are frequently regenerating using above both the methods. Nature includes a variety of species known as bio species participating a major role in formation of biological diversity in particular ecological areas. It is characterized by the presence of wide range of variation and variability among the species in certain area.
Each plant includes specific chemical compounds which differ to different plant species and is affected by alteration of various environmental factors. Amount of the plant products and their quality are together affected by climatic changes. Plants on the basis of their utility are categorized as food, fodder, fuel etc. A large group of plants with presence of certain chemical constituents are found to be effective in treatment of certain disorders for human beings are termed as medicinal and aromatic plants. Plants showing a rich variation in their habit and habitat such as herb, shrub, trees, climber etc and hydrophytes, mesophytes and xerophytes etc respectively. A numerous seeds produced by many of the plant species are efficiently reproducing new individuals like their mother plants. Most of the plant varieties in nature are propagating through their vegetative plant parts.

Around $80 \%$ of the medicinal plants are gained from forest areas in India and about $60 \%$ of the rural peoples directly rely on forest for their daily requirement 


\section{TABLE -2 : Family-wise distribution of Medicinal plants}

\begin{tabular}{|c|c|c|}
\hline $\begin{array}{l}\text { S. } \\
\text { No. }\end{array}$ & Family & $\begin{array}{c}\text { Number of } \\
\text { belonging } \\
\text { plants }\end{array}$ \\
\hline 1. & Acanthaceae & 1 \\
\hline 2. & Anacardiaceae & 2 \\
\hline 3. & Asclepiadaceae & 1 \\
\hline 4. & Asteraceae & 1 \\
\hline 5. & Combretaceae & 2 \\
\hline 6. & Dioscoreaceae & 1 \\
\hline 7. & Dipterocarpaceae & 1 \\
\hline 8. & Ebenaceae & 1 \\
\hline 9. & Euphorbiaceae & 1 \\
\hline 10. & Fabaceae & 6 \\
\hline 11. & Lamiaceae & 2 \\
\hline 12. & Lytharaceae & 1 \\
\hline 13. & Meliaceae & 1 \\
\hline 14. & Rutaceae & 2 \\
\hline 15. & Sapindaceae & 1 \\
\hline 16. & Sapotaceae & 1 \\
\hline 17. & Verbenaceae & 1 \\
\hline \multirow[t]{2}{*}{18.} & Zingiberaceae & 2 \\
\hline & TOTAL & 28 \\
\hline
\end{tabular}

like food, fodder, fuel and for medicine etc. Tribal peoples inhibiting near a forest area have rich knowledge on diversity and valuation of the plant species marked for medicinal purposes to treat specific disorders. These
Medicinal and Aromatic plants are efficiently used for the same purpose due to presence of potent natural chemical compounds. Its concentration and types are variable among the different Medicinal plants.

Some researchers did study on ethnomedicinal plants of the Khamti tribe of Arunachal Pradesh ${ }^{1}$. Some workers studied medicinal plants of two villages of Chakrata forest division and focused on ethnobiology notes on some tribes of Arunachal Pradesh, Northeast India ${ }^{2,3}$. There was study of plants used by Sheko ethnic group of In Ethiopia and Study on ethnomedicianal uses of indigenous plants of Kake Block, Ranchi Jharkhand ${ }^{4,5}$. Ethnomedico-botanical survey of Raipur Distric, C.G. state and Medicinal flora of Madhya Pradesh and Chattisgarh A review was done in $2003^{7,8}$. Folklore claims on some medicinal plants used by Bheel tribe of Guna district Madhya Pradesh were verified ${ }^{6}$. Current status of medicinal plants used by traditional Vaidyas in Uttaranchal state of India was recorded in $2005^{9}$. There were found some plants of folk medicine of Udaipur district, Rajasthan ${ }^{10}$. Ethnomedicinal plants were used by different tribes of Arunachal Pradesh ${ }^{11}$. There was Ethnomedico-botany of household remedies of Kolayat Tehsil in Bikaner distric, Rajasthan, and study on some ethno-medicinal plants of Chitrakoot district ${ }^{12,13}$.

Some abortifacient plants were used by tribal people of West Bengal ${ }^{14}$. An ethnobotanical Study of Medicinal Plants Used by the Tribes in Upper Subansiri District of Arunachal Pradesh and ethno medicinal plants used by Gonds of Adilabad district, Andhra Pradesh, India were recorded ${ }^{15,16}$. Ethnobotanical Uses of Plants among Bhotiya Tribal Communities of Niti Valleyin Central Himalaya, India was recorded ${ }^{17}$ ethno-botanical study at the Village Pondit Para under Palash Upazila of Narsingdi District, Bangladesh was also made ${ }^{18}$.

There was focus on ethno-medicinal application of plants in the eastern region of Shimoga district, Karnataka, India ${ }^{19}$ and utilization of medicinal plants as home herbalremedy in some urban areas of Kathmandu, Nepal ${ }^{20}$. There was study on ethnomedicinal plant resources of Mayurbhanj district, Orissa ${ }^{21}$ and Ethno medicinal plants used to cure different diseases by tribals of Mayurbhanj district of North Orissa were recorded ${ }^{22}$. A contribution of ethnomedicine of Alwar district of Rajasthan was done ${ }^{23}$.

An Ethnobotanical Study of Medicinal Plants in Chandauli District of Uttar Pradesh, India was made ${ }^{24}$. An ethno-botanical survey of medicinal plants used in Terai forest of western Nepal was done ${ }^{25}$. Ethnobotanical notes on the Hill Miri tribe of Arunachal Pradesh were prepared ${ }^{26}$. An ethnobotanical study of medicinal plants in Asgede Tsimbila District, Northwestern Tigray, Northern 


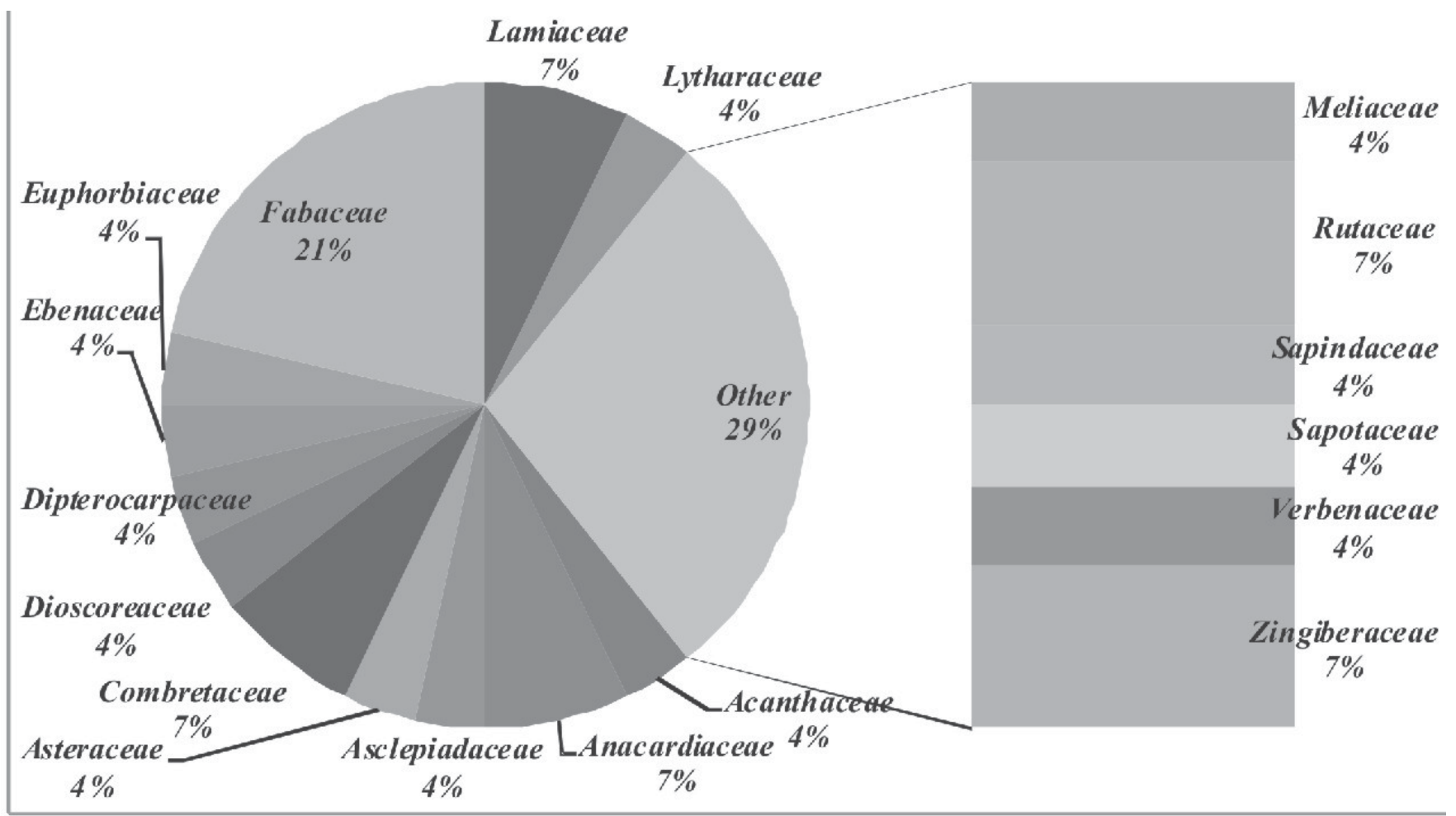

Fig. 1 : Family wise distribution of plants

TABLE -3 : Habit variation of the plants

\begin{tabular}{|l|l|c|}
\hline $\begin{array}{l}\text { S. } \\
\text { No. }\end{array}$ & Habit & $\begin{array}{c}\text { Number of } \\
\text { belonging } \\
\text { plants }\end{array}$ \\
\hline 1. & Herb & 6 \\
\hline 2. & Herb/Climber & 1 \\
\hline 3. & Shrub & 4 \\
\hline 4. & Tree & 17 \\
\hline & TOTAL & 28 \\
\hline
\end{tabular}

Ethiopia was done ${ }^{27}$.

\section{STUDY AREA}

This Ethnobotanical study was conducted in the villages of Kota Block in Bilaspur district of Chhattisgarh state in India. Study area/villages were adopted under the Unnat Bharat Abhiyan by the Guru Ghasidas Vishwavidyalaya (A Central University) Bilaspur, (Chhattisgarh). The area is located nearly $50 \mathrm{~km}$ away from the University campus. The area includes four gram
TABLE-4 : Propagation modes of different plants

\begin{tabular}{|l|l|c|}
\hline $\begin{array}{l}\text { S. } \\
\text { No. }\end{array}$ & Propagation mode & $\begin{array}{c}\text { Number of } \\
\text { belonging } \\
\text { plants }\end{array}$ \\
\hline 1. & Rhizome & 2 \\
\hline 2. & Seed & 22 \\
\hline 3. & Stem cutting & 3 \\
\hline 4. & Tuber & 1 \\
\hline & TOTAL & 28 \\
\hline
\end{tabular}

panchayat with nine villages. Whole area is surrounded by the forest. Tribal peoples are living in the area and having rich knowledge on Medicinal plants.

\section{Material and Methods}

Field visits were done (in adopted village by the Guru Ghasidas Vishwavidyalaya (A Central University) Bilaspur - Chhattisgarh - India) to achieve the present goal regarding ethnobotanical study on Medicinal and 


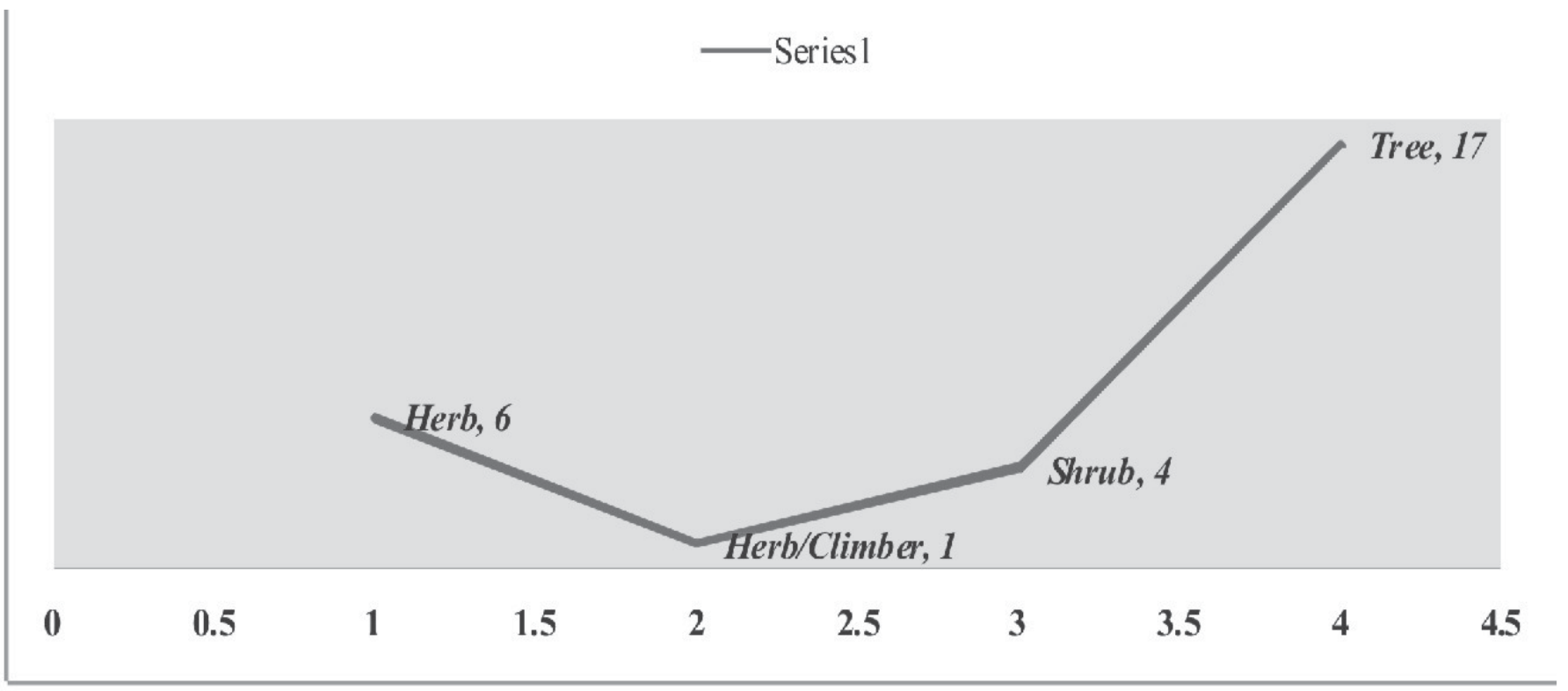

Fig. 2 : Habit variation of the plants

Aromatic Plants. Door to door survey was done and information was collected related to the uses of different plant species. Discussion made with Local traditional healers, Baigas for gaining the information on Medicinal plants.

\section{Results and Discussion}

The results of the present study are given in Tables.

During the present study in initial phase 28 plants were identified and gone for their study following their ethnomedicinal purposes with the help of Tribals/baigas of the villages of the study area. All Medicinal plants were separately tabulated in scientific manner following their local name, botanical name, family, habit, parts used, season of availability, traditional uses and propagation mode.

Recorded Medicinal plants belong to 18 different families. Out of which a maximum plant species 6 were

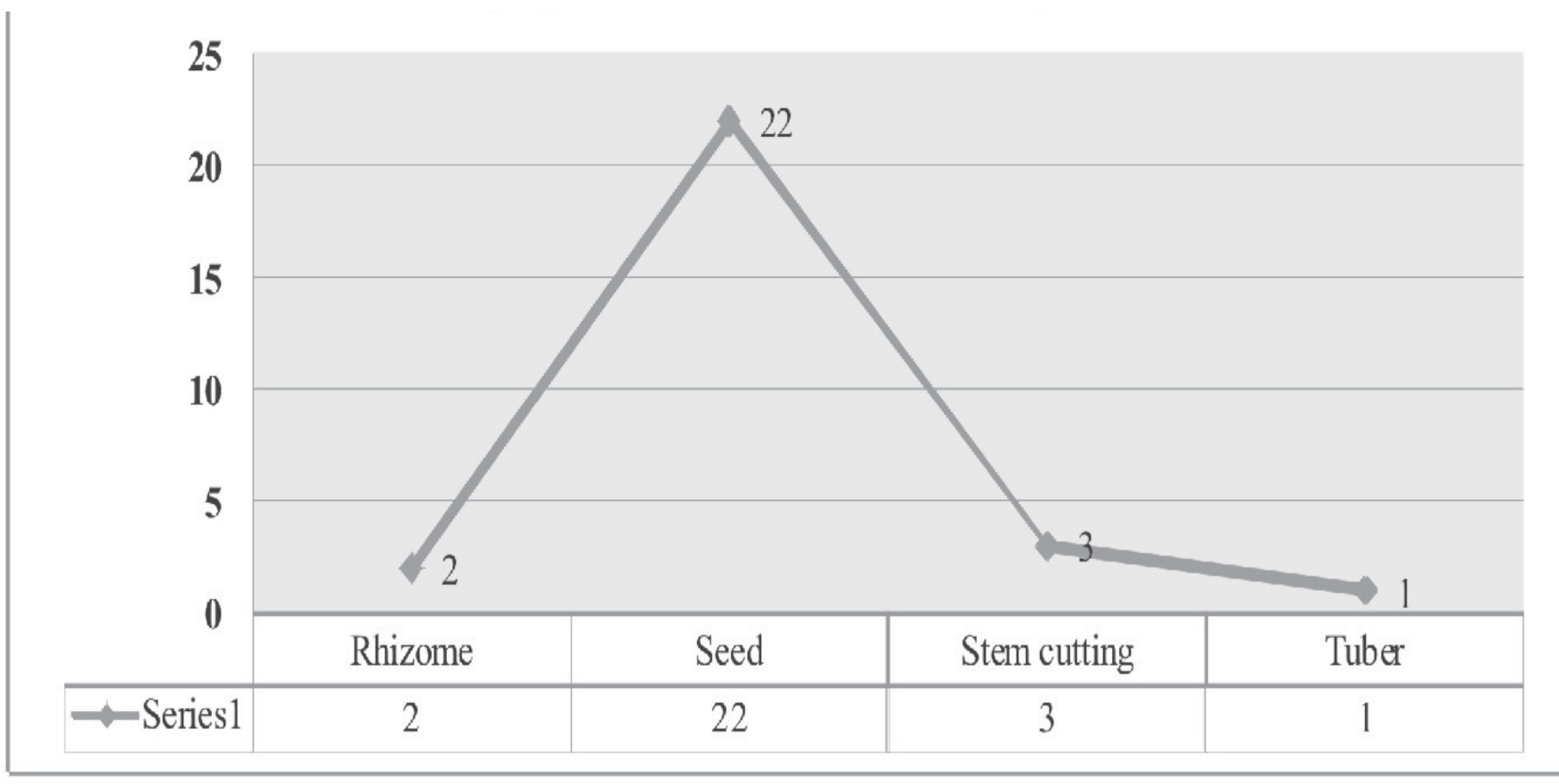

Fig. 3 : Propagation modes of different plants 
found as member of family Fabaceae. Two plants related to family Anacardiaceae, Combrataceae, Lamiaceae, Rutaceae and Zingiberaceae. Rest plants families included one medicinal plant species individually.

A maximum 17 tree habit medicinal plants and minimum 1 herb/climber were recorded. There were 6 herbaceous plants and 4 shrubs were also found. In propagation mode maximum 22 medicinal plant species were capable to propagate using their seeds. Other modes were by rhizome (2), Stem cutting (3) and by Tuber one plants registered.

\section{References}

1. Das AK, Tag H. Ethnomedicinal studies of the Khamti tribe of Arunachal Pradesh, Indian Journal of Traditional Knowledge. 2006; 5: 317-322.

2. Dobhal P, Sawan S, Sharma N. Studies on medicinal plants of two villages of Chakrata forest division, Uttarakhand, India. Ann of For. 2007; 15: 351-357.

3. Gangwar AK, Ramakrishnan PS. Ethnobiology notes on some tribes of Arunachal Pradesh, Northeast India. Economic Botany. 1990; 44: 94-105.

4. Gidaya M, Asfawb Z, Woldu Z. Ethno-medicinal study of plants used by Sheko ethnic group of Ethiopia. Journal of Ethnopharmacology. 2010; 132:75-85.

5. Ishwari PG. Studies on ethnomedicianal uses of indigenous plants of Kake Block, Ranchi Jharkhand. The Bioscan. 2009; 4 (1) : 85-87.

6. Jain AK, Vairale MG, Singh R. Folklore claims on some medicinal plants used by Bheel tribe of Guna district Madhya Pradesh, Indian J. Trad. Knowl. 2010; 9(1): 105107.

7. Jain JB, Kumane SC, Bhattacharya S. Medicinal flora of Madhya Pradesh and Chattisgarh: A review. Indian J. Trad. Knowl. 2006; 5(2): 237242.

8. Jain SP, Singh SC, Singh J, Kumar S. Ethnomedico-botanical survey of Raipur Distric, C.G. state. J.Econ. Taxon. Bot. 2003; 27(2): 266-271.

9. Kala CP. Current status of medicinal plants used by traditional Vaidyas in Uttaranchal state of India. Ethnobot Res Appl. 2005; 3 : 267-278.

10. Katewa SS, Arora A. Some plants of folk medicine of Udaipur district, Rajasthan. Ethnobotan. 1997; $9: 48-54$.

11. Khongsai M, Saikia SP, Kayang H. Ethnomedicinal plants used by different tribes of Arunachal Pradesh, Indian Journal of Traditional Knowledge. 2011 ; 10 (3): 541-546.

12. Kumar S, Goyal S, Parveen F. Ethnomedico-botany of household remedies of Kolayat Tehsil in Bikaner district, Rajasthan, India. J. TRad. Knowledge. 2003; 2 (4) : 357-365.

13. Kumar V, Sachan P, Nigam G, Singh PK. Some ethno-medicinal plant of Chitrakoot district (U.P.). Biozone Int. J. Life Sci. 2010; 2 (1 2): 270 - 283.

14. Mitra S, Mukherjee SK. Some abortifacient plants used by tribal people of West Bengal. Nat. Pro. Rad. 2009; 8 (2) : 167-171.

15. Murtem G, Chaudhry P. An Ethnobotanical Study of Medicinal Plants Used by the Tribes in Upper Subansiri District of Arunachal Pradesh, India. American Journal of Ethnomedicine. 2016; 3 (3) : 35-49.

16. Murthy EN. Ethno medicinal plants used by Gonds of Adilabad district, Andhra Pradesh, India. Int. J. Pharm. Life Sci. 2012; 3(10): 2034b- 2043.

17. Phondani PC, Maikhuri RK, Rawat LS, Farooquee NA, Kala CP. Ethnobotanical Uses of Plants among Bhotiya Tribal Communities of Niti Valleyin Central Himalaya, India. Ethnobotany Reserch \& Application. 2010; 8 : 233244.

18. Rahman AHMM, Debnath A. Ethno-botanical study at the Village Pondit Para under Palash Upazila of Narsingdi District, Bangladesh. International Journal of Advanced Research. 2015; 3(5): 1024-1039. 
19. Rajakumar N, Shivanna MB. Ethno-medicinal application of plants in the eastern region of Shimoga district, Karnataka, India. Journal of Ethnopharmacology. 2009; 126 (1):64-73.

20. Ranjitkar S, Rajbhandary S. Utilization of medicinal plants as home herbal-remedy in some urban areas of Kathmandu, Nepal. Journal of Plant Sciences. 2007; 2: 56-65.

21. Rout SD, Panda SK. Ethnomedicinal plant resources of Mayurbhanj district, Orissa. Indian J. Trad Know. 2010; 9: 68-72.

22. Rout SD, Panda T, Mishra N. Ethno medicinal plants used to cure different diseases by tribals of Mayurbhanj district of North Orissa. Ethno Med. 2009; 3 : 27-32.

23. Singh AG, Kumar A, Tewari DD. An ethno-botanical survey of medicinal plants used in Terai forest of western Nepal. J. Ethno-biol. Ethno-med. 2012; 8: 19.

24. Singh A, Singh PK. An Ethnobotanical Study of Medicinal Plants in Chandauli District of Uttar Pradesh, India, Journal of Ethnopharmacolgy. 2009; 121 (2): 324-329.

25. Singh GS. A contribution of ethnomedicine of Alwar district of Rajasthan. Ethnobotany. 1999; 11: 97-102.

26. Tag H, Das AK. Ethnobotanical notes on the Hill Miri tribe of Arunachal Pradesh, Indian Journal of Traditional Knowledge. 2004 ; 3(1): 80-85.

27. Zenebe G, Zerihun M, Solomon Z. An ethnobotanical study of medicinal plants in Asgede Tsimbila District, Northwestern Tigray, Northern Ethiopia. Ethnobotany Research and Applications. 2012; 10: 305-320. 